Jurnal Pakarena

Volume 4 Nomor 2, Desember 2020

e-ISSN: 2550-102X dan p-ISSN: 1693-3990

This work is licensed under a Creative Commons Attribution

4.0 International License

\title{
PERGESERAN FUNGSI KESENIAN SENJANG PADA MASYARAKAT MUSI BANYUASIN SUMATERA SELATAN; "ANTARA TRADISI DAN MODERNISASI DALAM ARUS GLOBALISASI"
}

\section{Irawan Sukma}

Keywords :

Senjang; pantun; instrumen; propaganda

\section{Corespondensi Author}

Dosen Seni Pertunjukan STKIP Muhammadiyah

OKUT

irawansukma462@gmail.com

History Artikel

Received: 01-11-2020

Reviewed: 01-11-2020

Revised: 23-12-2020

Accepted: 28-12-2020

Published: 30-12-2020

\section{ABSTRAK}

Artikel ini berkeinginan untuk memahami aspek-aspek yang melatar belakangi bagaimana suatu kesenian tradisi yaitu Kesenian Senjang yang berasal dari Kabupaten Musi Banyuasin Sumatera Selatan dijadikan sebagai sarana Propaganda sehingga mengalami pergeseran fungsi. Oleh karena itu artikel ini berusaha menjelaskan pergeseran fungsi yang dimaksud yang awalnya Kesenian Senjang digunakan sebagai sarana hiburan menjadi sarana propaganda untuk menyampaikan misi tertentu dari pengguna jasa Kesenian Senjang. Selain itu menjelaskan Kesenian Senjang dalam konteks sosialbudaya masyarakat Musi Banyuasin, mendeskripsikan bentuk Kesenian Senjang, pemaknaannya sampai pada fungsinya. Penelitian ini menggunakan metode kualitatif dengan tekhnik analisis interpretasi dan pendekatan kebudayaan, dan oleh karena itu menggunakan data kualitatif di mana peneliti sebagai instrumen utama dalam pengumpulan data. Sumber data yang menjadi sasaran penelitian adalah visual penyajian Senjang dan rekaman audio visual Senjang di Sekayu ibukota kabupaten Muba. Selain itu metode etnografi juga digunakan dengan pendekatan emik dan etik guna menemukan permasalahan yang sebenarnya terjadi. Senjang Musi Banyuasin adalah subjek utama dari penelitian ini, dengan menggunakan metode kualitatif interpretatif dalam pengolahan data, menganalisis keberlangsungan Senjang dari masa ke masa yang mengalami perubahan baik bentuk maupun fungsinya. Senjang yang pada awal keberadaannya memiliki bentuk yang sederhana tanpa instrumen musik, terus bergerak dan berkembang mengikuti arus zaman sampai pada era saat ini. Tampilan Senjang sudah lebih pada komersial tergantung keinginan pengguna jasa. Fungsi Senjang dimanfaatkan sebagai media propaganda bagi penguasa. Senjang masih eksis 
Jurnal Pakarena, Volume 4 Nomor 2, Desember 2020

dan memiliki tempat tersendiri di hati masyarakat Kabupaten Musi Banyuasin. 


\section{PENDAHULUAN}

Setiap daerah memiliki ciri khas dan karakteristik yang saling berbeda dan dipengaruhi oleh lingkungan sesuai kondisi daerahnya masing-masing.Hal ini senada dengan apa yang disampaikan oleh Arnold Hauser (1974: 547) bahwa perubahan sosial di sebuah wilayah akan menghasilkan kesenian yang khas sesuai dengan bentuk masyarakat pada waktu itu. Seperti halnya Kabupaten Musi Banyuasin (Muba), sebagai salah satu daerah di Sumatera Selatan, dengan Ibu Kotanya Sekayu memiliki kesenian yang khas yakni Senjang.

Senjang adalah salah satu bentuk kesenian yang menggunakan media pantun yang dinyanyikan secara bersahutan antara dua orang baik secara berpasangan maupun sendirian, secara spontanitas atau tidak secara spontanitas, dengan gerakan menari dan perangkat musik tanjidor pada awalnya (saat ini keyboard). Senjang yang semula merupakan hiburan, karena disetiap kesempatan, misalnya saat berkumpul dengan kelompok-kelompok masyarakat, senjang sering dilantunkan. Di setiap kecamatan yang ada di Kabupaten Muba (ada 14 kecamatan) dipastikan ada kelompok Senjang, sebut saja Kecamatan Sungai Keruh, Kecamatan Sungai Lilin, Kecamatan Sanga Desa, Kecamatan Bayung Lincir, Kecamatan Babat Supat, Kecamatan Babat Toman, Kecamatan Tungkal Jaya, Kecamatan Lais, Kecamatan Batanghari Leko, Kecamatan Lawang Wetan, dan lainlain yang masih eksis keberadaannya. Ini terlihat dari pelaksanaan Festival Randik setiap tahunnya, dimana setiap kecamatan mengirim wakilnya kelompok Senjang.

Senjang saat ini menjadi media kontrol masyarakat dalam menyampaikan aspirasi kepada pemerintah, baik pemerintah di lingkungan pedesaan (Kepala Desa) maupun pemerinta kabupaten (Bupati) bahkan pemerintah propinsi (Gubernur) atau pemerintah pusat (Presiden). Seperti yang terjadi di desa Sungai Keruh tepatnya di desa Tebing Bulang yang jaraknya 30 kilometer dari Kota Sekayu, saat penulis melakukan penelitian di desa tersebut. Dari informasi yang didapat melalui wawancara dengan masyarakat setempat yaitu ibu Kartini (70 tahun) warga kampung I desa Tebing Bulang, dikatakan bahwa Senjang sudah ada sejak ia masih kecil, orang tuanya sering mengajaknya untuk menonton pertunjukan Senjang disetiap acara-acara pesta rakyat, bahkan saat tuan Konger (Belanda) menjadi Residance di Sekayu tahun 1836. Ini dibuktikan dengan adanya temuan Bunker/Camp ex-Belanda di Talang Pengadang dusun 3 Desa Rantau Kasih Kecamatan Lawang Wetan oleh tim arkeologi dinas Pariwisata Muba pada tanggal 6 Februari 2014. Dari temuan tersebut diperkirakan Belanda membangun Bunker tersebut sebelum kemerdekaan RI, dan diperkirakan pada tahun 1932 Belanda meninggalkan Sekayu.

Kesenian Senjang merupakan bentuk kesenian tradisional berupa sastra tutur (pantun) yang di sajikan dalam bentuk nyanyian yang berirama. Senjang asal kata dari kesenjangan yaitu permasalahan yang timbul dimasyarakat sebagai efek dari respon kepada kepada pemerintah yang mengacu pada standar hidup relative dari seluruh masyarakat, sehingga menimbulkan gap atau jurang dalam wilayah tersebut. Mengapa disebut Senjang karena antara lagu dan musik tidak saling bertemu seperti pada umumnya sebuah lagu. Artinya saat syair lagu dinyanyikan musik berhenti, begitupun sebaliknya saat musik bermain penyanyi diam, sehingga kedua sisi ini tidak bisa saling bertemu. 


\section{BENTUK DAN FUNGSI KESENIAN SENJANG}

\section{Era Pra-Kemerdekaan}

Kesenian Senjang secara turuntemurun dari nenek buyut sampai ke cucu dan keturunannya sekarang, diperkirakan telah ada pada zaman Pedatuan. Ia bisa bersenjang dikarenakan belajar secara otodidak dengan melihat orang tua, tetangga, para sesepuh dan rekan- rekan yang seumur dengannya melakukan aktifitas bersenjang di teras-teras rumah. Karena sering melihat akhirnya ia bisa menirukan pantun-pantun yang disampaikan (Kartini, wawancara 27 Mei 2014).

Sebelum era kemerdekaan atau zaman penjajahan, sekitar tahun 1930-an, Senjang ditampilkan tidak menggunakan alat musik, hanya berupa pantun bersahut. Saat itu penampilan Senjang sangat sederhana sekali. Namun demikian makna yang disampaikan sangatlah jelas, tidak bermuatan politik atau propaganda hanya sebagai hiburan pengungkapan hati saja, namun unsur budaya dan bahasa yang digunakan khas Kabupaten Muba (Dadang Irawan, wawancara 5 Februari 2014).

Perlu disadari bahwa nyanyian rakyat sebagai bagian dari folklor memiliki dua unsur, yaitu kata-kata (ucapan vocal) dan lagu (musik) yang tak dapat dipisahkan (Danandjaja, 1991:141). Dalam buku Ilmu Melodi, Dieter Mack menyebutkan:

“...ucapan vocal merupakan sumber melodi yang paling asli dan murni bagi manusia. Akan tetapi bukan setiap ucapan vocal harus menimbulkan suatu melodi (baca: "melodi" adalah "jiwa musik") sebagai unsur utama musik (Dieter Mack, 1995: 16).

Pada era Pra-kemerdekaan, bentuk instrumen Senjang belum ada. Hal ini dikarenakan seniman Senjang masih menganggap Senjang hanyalah berupa pantun bersahut belaka. Selain itu keberadaab alat musik pada zaman kolonial dan dikolonial masih sangat langkah. Alasan inilah yang membuat musik Instrumen Senjang belum dapat dibuat (Abdul Malik, wawncara 25 Mei 2014).

Contoh syair pantun Senjang yang dibawakan sebelum kemerdekaan atau pada zaman Kolonial.

Endok Kopek Gunung Klarang

Kitek Gendang Pangkut-pangkut

Kitek Gendang Ngangkut padi

Terulam Pang Ladi

Wewe Bawa Monel, Ingge Metu Samesame
Endok Adek Gunung Klarang
Kitek Senjang Pantun-pantun
Ntuk Nngeman Siang Ari
Weng Tue Suka Ngane
Kitek Batemu Jarang Kale
Juba-juba Ngarang Rempa
Kalu Boleh Silat Tari
Ngambek Salak Bawa Surak
Adat Prane Ubi kayu
Endok Adek Gunung Klarang

Bentuk lagu syair pantun Senjang pada dasarnya bersifat melismatis, artinya tidak diikuti oleh instrumen musik. Namun sebelum memulai syair pantun Senjang biasanya diawali dengan intrumen musik Senjang. Pada 20 Maret 1942 pemerintah pendudukan Jepang menetapkan Undangundang no 3 yang isinya melarang kegiatan perkumpulan mulai dari gerakan organisasi politik, ekonomi, dan sosial serta budaya. Namun melihat perkembangan sosial serta budaya, khususnya seni pertunjukan Indonesia, bertentangan dengan kebijakan pemerintah Jepang kala itu. Para pemimpin Jepang mulai sadar terhadap seni pertunjukan Indonesia terutama bersifat hiburan. Seni pertunjukan Indonesia sejak itu sering disajikan dalam berbagai acara suguhan 
misalnya untuk menjamu tamu dan pembesar Jepang ( Slamet MD, 2012:148-149).

Hal itu berpengaruh pada kesenian Senjang yang ada di Musi Banyuasin. Senjang difungsikan untuk menjamu tamutamu kehormatan para penguasa Belanda dan Jepang yang berkedudukan di Sekayu. Kedudukan dan fungsi Senjang kala itu hanya sebatas hiburan.

\section{Era Pasca Kemerdekaan}

Presiden Soekarno kala itu menganut prinsip anti Barat, dimana beliau menentang keras hal-hal yang berbau asing masuk ke Indonesia. Hal ini memberikan peluang bagi para seniman Indonesia untuk lebih kreatif dalam berkarya (Ben M. Pararibu, 2006:126).

Senjangpun mengalami perubahan, yang sedikit banyak memberikan nuansa baru bagi pertunjukan Senjang. Jika era sebelum kemerdekaan Senjang ditampilkan tanpa instrumen musik, setelah kemerdekaan Senjang tampil dengan instrumen musik. Awal mulanya Senjang tampil dengan seperangkat alat musik Jidor (Abdul Malik, wawancara 25 Mei 2014).

Malik menuturkan bahwa musik Jidor adalah musik yang diadopsi dari musik Betawi. Sekitar tahun 1950-an, seorang pengusaha di Sekayu atas saran Jeling seorang pendatang dari Jakarta yang lama menetap di Sekayu, untuk membeli alat musik Jidor tersebut. Hal itu dilakukan karena pengusaha itu tertarik dan senang mendengarkan kemeriahan musik Jidor saat dimainkan. Kemudian, Malik dan kawankawan pemusik, berkumpul latihan bersama memainkan alat musik Jidor. Lalu muncullah ide untuk membuat musik instrumen Senjang. Dengan kemampuan yang ada akhirnya terciptalah alat musik Senjang secara terbatas (Abdul Malik, wawancara 25 Mei 2014).

Selanjutnya musik tersebut dipadukan dengan syair-syair pantun Senjang, sehingga terciptalah bentuk sajian Senjang yang menarik. Karena disajikan dengan polesan musik Jidor, kemeriahan Senjangpun terlihat jelas. Ini terbukti setiap Senjang ditampilkan banyak sekali masyarakat yang berbondongbondong ingin menyaksikan pertunjukan Senjang. Inilah awal cikal bakal kesenian Senjang ditampilkan dan ditonton oleh masyarakat luas dengan perpaduan antara musik dan syair pantun Senjang. Banyak sekali lahir para seniman Senjang yang mampu membuat syair pantun Senjang secara spontan saat tampil. Tanpa melihat teks, para pe-Senjang dapat tampil dan memikat hati para penontonnya (Abdul Malik, wawancara 25 Mei 2014).

Kesenian Senjang pada era Pasca Kemerdekaan, sekitar tahun 1950-1962 berfungsi sebagai sarana hiburan rakyat, dimana pada awalnya sebagai sarana pergaulan dan komunikasi antar warga masyarakat sekitar kampung di lingkungan kabupaten Musi Banyuasin (Animah, wawancara 27 Mei 2014).

Terlihat jelas sekali, pada era sebelum Orde Baru Senjang ditampilkan sebagai alat propaganda pemerintah bagi masyarakat untuk menumbuhkan semangat kebangsaan, rasa cinta tanah air serta persatuan dan kesatuan. Seperti penyampaian kebijakan pemerintah dalam program pemberantasan buta huruf ( $\mathrm{T}$ Slamet Suparno, 2009:143).

\section{Era Orde Baru}

Era Orde Baru, sekitar tahun 1966, stabilitas ekonomi dan keamanan semakin membaik. Banyak seni pertunjukan di Indonesia mengarah pada seni populer, dimana Rezim Orde baru mengeksploitasi seni pertunjukan dengan memberikan kebebasan untuk menciptakan dan mengembangkannya, namun otoritas Orde Baru lebih cenderung memfungsikan beberapa seni pertunjukan Indonesia salah satunya adalah pakeliran 
sebagai alat propaganda politik dan/atau corong pembangunan, serta hiburan. Era Orde Baru, kebudayaan bersifat politis, seni tidak lepas dari kepentingan dan muatan politik (Joost Smiers, 2003:87; T. Slamet Suparno, 2009:39-40).

Senjangpun mengalami kemajuan yang pesat, meski mengalami hegemoni yang sama dengan kebudayaan Nusantara. Pada era Orde Baru, pertunjukan Senjang masih menggunakan musik Jidor, bahkan pada era tahun 70-an sampai tahun 80-an, Senjang mengalami masa kejayaan. Hampir disetiap kecamatan yang ada di Kabupaten Muba (dahulu ada 11 kecamatan) telah memiliki kesenian Senjang. Terbukti bupati Amir Hamzah pada saat itu menjabat sebagai Bupati Musi Banyuasin, sekitar tahun 1978, sering mengumpulkan para seniman Senjang dan para Pesirah, serta Kepala Desa di Pendopoan Bupati hanya sekedar untuk bersilaturahmi. Senjang kala itu sudah istimewa (Tarmizi, wawancara 25 Mei 2014).

Pada era Orde Baru seni dimanfaatkan penguasa Orde Baru untuk menyampaikan program-program pembangunan. Di era ini pelaku bisnis terhadap Seni Pertunjukan di Indonesia bermunculan. Hal serupapun turut dirasakan oleh para seniman Senjang dimasa era Orde Baru. Mereka dimanfaatkan untuk menyampaikan program pemerintah pusat melalui visi dan misi pemerintah daerah. Seperti contoh saat pencanangan program Keluarga Berencana (KB) yang mengharuskan rakyat indonesia untuk memiliki dua anak cukup. Program ini pun disampaikan melalui kesenian Senjang.

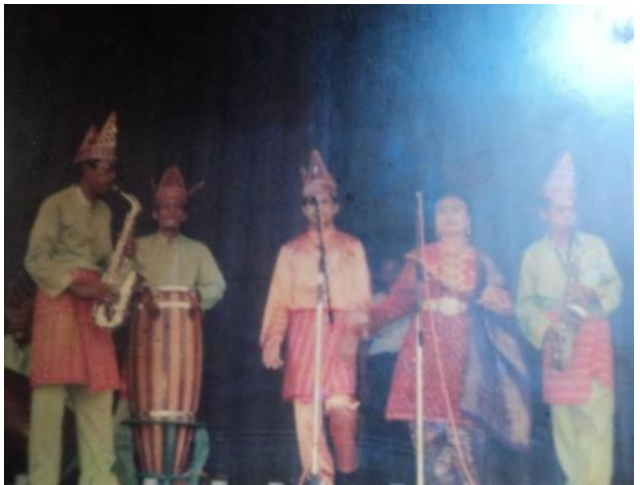

Gambar Senjang yang ditampilkan bersama musik Jidor di era tahun 80-an. ( Foto Irawan Sukma, 2014)

\section{Era Reformasi}

Era Reformasi adalah fase dimana bangsa Indonesia mengalami perubahan secara signifikan, dari seluruh aspek kehidupan memiliki tujuan dan arahan untuk mencapai sisi kehidupan yang lebih layak, dengan mengedepankan kepentingan rakyat. Pada era Reformasi, hampir semua kesenian mengalami kemajuan baik secara fisik maupun bentuk sajian. Para seniman diberikan ruang gerak yang bebas, tidak lagi memandang etnis tertentu sebagai sesuatu perbedaan.

Senjang tidak mengalami perubahan yang signifikan, meskipun elemen-elemen lainnya mengalami perubahan karena pengaruh Reformasi. Hanya saja musik instrumen Senjang jika pada era Pasca Kemerdekaan dan Orde Baru menggunakan seperangkat musik Jidor, maka sejak tahun 1998 dengan maraknya kehadiran keyboard, maka musik instrumen Senjangpun berubah. Dengan alasan bahwa kecanggihan keyboard yang dapat mengaplikasikan beberapa jenis suara alat musik, sehingga suara alat musik tersebut dapat terwakilkan. Faktor efisiensi inilah yang memperkuat kehadiran keyboard di masyarakat. Namun masih ada pengguna jasa Senjang yang menginginkan musik Jidor saat dipentaskan, dengan alasan suara musik Jidor lebih halus dan terkesan tradisional (Habibi, wawancara 27 Mei 2014). 
Kesenian Senjang sebagai seni pertunjukan yang berkembang secara lisan, memiliki kebebasan intepretasi dan imajinasi para senimannya yang diwujudkan melalui garap. Seperti yang dikatakan Rahayu Supanggah, garap memiliki arti dan kedudukan yang cukup penting dalam seni pertunjukan yang menyangkut imajinasi, interpretasi, dan kreatifitas senimannya dalam mengembangkan karya seni yang disajikan (Rahayu Supanggah 1987: 21).

Garap yang telah dilakukan oleh para seniman Senjang antara lain: aransemen musik instrumen Senjang, dibuat dengan berbagai jenis instrumen alat musik, dinamika vocal yang harmonis, syair pantun bervariasi, dan bentuk penyajian yang kompleks dengan penambahan penari latar. Hal ini mempuat tampilan Senjang memiliki warna baru dan tidak monoton, namun demikian isi syair pantun Senjang pada era Reformasi lebih banyak pada pujian dan sanjungan, kritik yang bersifat membangun bahkan sudah mengarah pada kondisi yang saat ini sedang terjadi dan ramai dibicarakan banyak orang. Artinya tampilan Senjang lebih mengarah ke hiburan dan dapat memberi kepuasan bagi penikmat Senjang maupun pengguna jasa Senjang.

Senjang di era sekarang, masih memiliki fungsi yang sama seperti pada era Orde Baru yakni sebagai media propaganda, untuk penyampaian maksud dan tujuan dari pengguna jasa kesenian Senjang itu sendiri, tidak hanya penguasa. Hal itu sangat tergantung pada kondisi setempat dan persentuhan serta pengaruh lingkungannya. Pada era Orde Baru dan era Reformasi Senjang difungsikan untuk menyampaikan slogan-slogan dari program pemerintah, seperti buta huruf, Keluarga Berencana, Cinta Rupiah dan paling jelas terlihat dimanfaatkan oleh para calon- calon legislatif untuk kepentingan politik (Tarmizi, wawancara 25 Mei 2014).

\section{KESIMPULAN}

Pertama, kesenian Senjang merupakan kesenian tradisi lisan Sumatera Selatan yang masih ada dan terus berkembang di daerah Kabupaten Musi Banyuasin. Kedua, bentuk kesenian Senjang mengalamai perubahan dari setiap periodisasinya, Ketiga, fungsi Senjang pada masyarakat Kabupaten Musi Banyuasin mengalami perluasan, jika pada awal mulanya Senjang berfungsi sebagai sarana hiburan dan komunikasi masyarakat, atau sekedar menyampaikan nasehat, kini berkembang menjadi media propaganda, baik propaganda politik, ekonomi, sosial dan budaya, yang pada hakekatnya bertujuan untuk kemaslahatan kesenian Senjang itu sendiri ditengah-tengah masyarakat. Keempat, peran serta dan perhatian pemerintah serta dukungan masyarakat untuk menegaskan dan mematenkan (HAKI) kesenian Senjang sebagai salah satu warisan budaya tak benda sangatlah diperlukan. Hal ini sudah dilakukan, sehingga Senjang memiliki identitas yang kuat bagi masyarakat Kabupaten Musi Banyuasin. Kelima, Senjang tidak hanya sekedar hiburan bagi pelaku dan penikmat seni, tapi lebih dari itu Senjang mampu dijadikan "periok nasi" bagi seniman Senjang dalam meningkatkan ekonomi keluarga. Karena masih banyak pengguna jasa Senjang yang memanfaatkan pertunjukan Senjang untuk berbagai kebutuhan, tidak hanya sebagai privacy belaka. Berdasarkan hal tersebut terlihat jelas bahwa kesenian Senjang mengalami perkembangan dikarnakan sering dijadikan sebagai media propaganda dalam menyampaikan informasi maupun tujuan dari pengguna jasanya, sebagai contoh untuk mencalonkan diri menjadi seorang Bupati atau caleg media propaganda yang tepat untuk menarik massa melalui kesenian senjang, atau untuk menyampaikan program pemerintah baik visi maupun misinya, 
kesenian Senjang berperan langsung karena dapat langsung berinteraksi dengan masyarakat. Inilah yang menyebabkan kesenian Senjang dijadikan sebagai media propaganda, selain memiliki nilai praktis juga memiliki nilai ekonomis dimana pengguna jasa tidak harus mengeluarkan biaya yang besar untuk membuat iklan dalam menyampaikan informasi.

\section{DAFTAR PUSTAKA}

Boskoff, Alvin, "Recent Theories of Social Change" dalam Werner J. Chanman dan Alvin Boskoff (ed), Sociology and History: Theory and Research. London: The Free Press of Glencoe. 1964.

Dinas Kebudayaan dan Pariwisata Sumatera Selatan, Direktori Kesenian Sumatera Selatan, Palembang, Sumatera Selatan. 2006

G. Tan, Melly, Etnis Tionghoa di Indonesia. Jakarta: Yayasan Obor Indonesia. 2008.

Hauser, Arnold, The Sociology of Art. Transled by Kenneth J.Northcott. Chicago and London: The University of Chicago Press. 1974.

Langer, K.Suzanne, "Problematika Seni". Terjemahan fx. Widaryanto.STSI Bandung, Sunan Ambu Press. 2006.

Murtana, I Nyoman, Seni \& Politik. Surakarta: ISI Press. 2010

Ratna, Nyoman Kutha, Metodologi Penelitian Kajian Budaya dan Ilmu Sosial Humaniora Pada Umumnya. Denpasar: Pustaka Pelajar. 2010.
Slamet MD, Barongan Blora, Menari di atas Politik dan Terpaan Zaman. Surakarta: Citra Sains.2012.

Supanggah, Rahayu, "Musik Bambu Banyumasan”, Laporan Penelitian untuk The Ford Foundation. Jakarta. 1981. , Bothekan Karawitan I. Jakarta. Masyarakat Seni Pertunjukan Indonesia. Dan Bothekan Karawitan II Garap. 2002. ISI Press Surakarta. 2002.

Suparno, T. Slamet, Seni Sebagai Produk Masyarakat Ataukah Masyarakat Sebagai Produk Seni, Pidato Pengukuhan Guru Besar Bidang Ilmu Sosiologi Seni. Surakarta: ISI Press Solo. 2008.

Pakeliran

Wayang Purwa, dari Ritus sampai Pasar. Surakarta: ISI Press Solo. 2009. 